\title{
Effect of planting distances and Humic Acid application on some vegetative growth and yield of Broad bean (Vicia faba L. var. Somar) in outdoor condition
}

\author{
Chnar Hama Noori Meerza \\ Department of Protected Agriculture \\ Bakrajo Technical Institute \\ Sulaimani Polytechnic University \\ Sulaimani, Iraq \\ Chnar.meerza@spu.edu.iq
}

\author{
Arsalan Azeez Marif \\ Department of Horticulture \& Landscape Design \\ Bakrajo Technical Institute \\ Sulaimani Polytechnic University \\ Sulaimani, Iraq \\ Arsalan.marif@spu.edu.iq
}

\author{
Ardalan Jalal Majeed \\ Department of Horticulture \& Landscape Design \\ Bakrajo Technical Institute \\ Sulaimani Polytechnic University \\ Sulaimani, Iraq \\ Ardalan.majeed@spu.edu.iq
}

\begin{abstract}
The seeds of the Somar variety (local production) were planted in mid of October (after being soaked with water for 16 hours) in panels $1.5 \times 2$ meters. Broad bean (Vicia faba var. Somar) was studied in outdoor to determine the effect of three planting distances $(20,25$ and $30 \mathrm{~cm})$, four different Humic Acid $\left(H^{A}\right)$ concentration doses (zero, 1.5, 3.0 and 4.5) $\mathrm{ml} /$ liter $\mathrm{H}_{2} \mathrm{O}$, with three replicates on some of the plant's vegetative and yield traits; Plant Height (cm), Plant Diffusion (cm), Number of Branches /Plant, Number of Flowers / Plant, Number of Pods / Plant, \% percentage of Pods Set, Total Pods Yield /plant (gm), Pod Weight (gm). The $\left(\mathrm{H}^{A}\right)$ were added by spray way directly to the top of the soil with two applications, the first after 3 weeks from complete germination, while the second after branching immediately. The experiment was designed as Randomized Complete Block Design (RCBD). Based on Total pods yield / plant (gm), the best interaction between the plant distance and different concentration of $\left(H^{A}\right)$ was a combination of the planting distance 30 $\mathrm{cm}$, and treated the soil with $3.0 \mathrm{ml} /$ liter $\mathrm{H}_{2} \mathrm{O}$.
\end{abstract}

Keywords: Broad bean, planting distance, Humic acid, Vegetative and yield traits.

\section{INTRODUCTION}

Broad bean, Faba bean, Fava bean or Horse bean (Vicia faba L.) belongs to Fabaceae Papilionaceae family is one of important vegetable crops, which contains highest nutritional value from the rest of the legume crops (contain protein 21.6, carbohydrate $61.2 \mathrm{gm} / 100 \mathrm{gm}$ dry seeds) compared with the second legume crop (lemma bean), which contains protein 17.1 and carbohydrate $57.3 \mathrm{gm} / 100 \mathrm{gm}$ dry seeds [1]. There are many factors affecting on vegetative growth and yield in broad bean cultivation, these are: plant density varieties ,which are used, irrigation system, fertilization treatment and the length of growing season from seeds sowing until the end of harvesting [2].
The distances within plants and $\left(\mathrm{H}^{\mathrm{A}}\right)$ concentration sprayed on the soil between agriculture lines is one of effective factors, which deserve study and research, but caution should be taken from the fall of $\left(\mathrm{H}^{\mathrm{A}}\right)$ spray on the leaves of cultivated plants because it causes burns in them [3].

The agricultural distances lower or higher than the ideal distance and its effect on the vegetative growth characteristics and production are studied by many researchers. [4] has studied the effect of plant distances $(20,3040.50 \mathrm{~cm}$ within plants) on plant height $(\mathrm{cm})$, number of branches / plant, number of pods/ plant, mean pod weight $(\mathrm{gm})$, number of seeds / pod, mean seeds weight/ pod (gm) under drip irrigation system. They indicated that the higher the planting distances, the lower in the plant height, because in small spaces the competition between plants increases on sunlight. The number of branches / plant are increased with increasing the plant distances, while [5] indicated that planting 12 plants $/ \mathrm{m}^{2}$ achieved significant lower plant height $\mathrm{cm}$ compared with 10 plants $/ \mathrm{m}^{2}$ and this plants number / $\mathrm{m}^{2}$ achieved significant lower plant height than 8 plants / $\mathrm{m}^{2}$, under the conditions of the irrigation. However, [6] cultivated five faba bean varieties (Cairo -4, Cairo -5, Cairo -25, Nubaria -1 and Giza -843) each with 24, 21, 18,15 and 12 plants $/ \mathrm{m}^{2}$ in newly reclaimed sandy soils. Results indicated that faba bean varieties varied significantly in all studied characters, indicated that in this type of soil 18 followed with 16 plants $/ \mathrm{m}^{2}$ were better plant density than others. The broad bean is from a short day plant, which needs than 12 hours light / day (about $8-10$ hours), with cold humid weather to achieve better blossom and pods set [7]. These conditions are located in the meddle and northern regions of Iraq [8], and that increasing the length of the day to 12 hours and the high temperature of $17 \mathrm{C}^{0}$ will lead to a decline in flowering and fall of flowers [2]. It is also necessary not to spray any foliar fertilizers or pesticides during the flowering period because this causes flowers fall off [9]. The development of pod, seed growth of faba bean in the field in early and late planting of early-middle ripening varieties were studied by [10], deciding that early 
sowing seeds for these varieties, resulting in poor pollination of flowers due to lower temperatures (frosting) during the floral period, and as the end the pods set are greatly reduced, while late sowing seeds of these varieties resulting in floral fall down, due to high temperatures during the floral period, that lead to the death of flower pollen, especially in the case of low humidity in such circumstances. For this reason, the varieties are grown on suitable time for the conditions of the cultivated area, so the local variety Somar can be cultivated in the beginning of October to the midNovember in the central of Iraq, and from midNovember to the end of December in the northern of Iraq [11].

$\left(\mathrm{H}^{\mathrm{A}}\right)$ is located at the ubiquitous of the Earths layer which is known as plants brown-black colored polymeric acids at the Earth's surface. When all of the organic compounds is available in the soil this kind of soil is known as humus. The mineral nutrients can be converted into an available form of nutrient by the availability of $\left(\mathrm{H}^{\mathrm{A}}\right)$. The viability and germinations of the plant seeds is stimulated by $\left(\mathrm{H}^{\mathrm{A}}\right)$ however; it impacts mostly on the root parts of the plant [12]. Many researchers have investigated for several decades that the microbial changes in the plant lignin cause the formation of the above mentioned $\left(\mathrm{H}^{\mathrm{A}}\right)$ However, an experiment to test whether these $\left(\mathrm{H}^{\mathrm{A}}\right)$ were formed prior to plant matter reaching the soil, one of the first recognized supplies of Leonardite originated from the Dakotas, (named after a Mr. Leonard). These layer of the soil were not very deep by which a few depth of the soil required mining. At the beginning all of the Humic and Fulvic acid which contained mined products were known as Leonardine term. Mined products. According to the results of this study due to recycling of plants and algal matter the soil can be filled with $\left(\mathrm{H}^{\mathrm{A}}\right)$ or the addition of the outer layer of the plant decomposition or algal matter which includes, composts, mulch, peat, and lignite known coals in the roots of Faba beans crop [13].

According to a study done by [14] $85 \%$ of $\left(\mathrm{H}^{\mathrm{A}}\right)$ impacted on the root part of the plant while used with concentration of $2-4 \mathrm{ml} /$ liter distilled water which caused root growth stimulation as well as caused formation of a strong radicle which consequently the floral and vegetative growth increased. Based on the final result of this study the number of fruits set (pods set) is high as well as maturity stage which consequently led to an increase in the plant pods set due to the treatment of soil with $\left(\mathrm{H}^{\mathrm{A}}\right)$. In addition, these increases in the pods set were due to the raises of the roots surface area and depth. Despite of the significant effect of $\left(\mathrm{H}^{\mathrm{A}}\right)$ on plant but there is a limitation in the applied concentration of $\left(\mathrm{H}^{\mathrm{A}}\right)$ in which when higher concentration than the permissible amount is used leads to the death of the root parts of the plant as well as the foliar application of $\left(\mathrm{H}^{\mathrm{A}}\right)$ causes burning in the leaf parts [15].

The addition of the $\left(\mathrm{H}^{\mathrm{A}}\right)$ to the soil leads to reduce the $\mathrm{pH}$ of soil's solution, and then it is used for reclamation of alkaline land to reduce the alkalinity from $\mathrm{pH} 8$ or more to $\mathrm{pH} 6$ or at least $\mathrm{pH} \mathrm{7,} \mathrm{when} \mathrm{trying} \mathrm{to} \mathrm{cultivate}$ two faba bean varieties in the alkaline fields of the Faculty of Agriculture, Diyala University [16].
The objective of the present study was to determine the effect three planting distances, four different $\left(\mathrm{H}^{\mathrm{A}}\right)$ concentration doses on some vegetative growth and yield of broad bean (Vicia faba L.) cultivar.

\section{MATERIAL AND METHODS}

Half $\mathrm{kg}$ seeds of broad bean (Somar local variety) were obtained from the Agricultural Research Center in Sulaymaniyah, soaked in water about 16 hours, then water was removed from the seeds and planted on lines in panels $1.5 \times 2$ mater (the distance between lines 40 $\mathrm{cm}$ ) using two seeds in one hole. The research was designed according to the complete random design in the factorial experiment, with two factors, first was the planting distances, which include three distances $(20,25$ and $30 \mathrm{~cm})$, while the second factor was the $\left(\mathrm{H}^{\mathrm{A}}\right)$ concentrations, which include four concentrations (zero, 1.5, 3.0 and $4.5 \mathrm{ml} /$ liter distilled water).

The Physical and chemical properties of the soil used in the study: was shown in Table 1 defined by $[17,18,19]$.

Table 1: Characteristics of the soil used in the study

\begin{tabular}{lc}
\hline Parameters & Sample Value \\
\hline $\mathrm{pH}$ & 7.65 \\
Electric Conductivity (mmhos/cm) & 1.56 \\
Calcium Carbonate $(\%)$ & 32.1 \\
Organic matter $(\%)$ & 2.48 \\
Calcium $\left(\mathrm{mgkg}^{-1}\right)$ & 4322 \\
Magnesium $\left(\mathrm{mgkg}^{-1}\right)$ & 280.78 \\
potassium $\left(\mathrm{mgkg}^{-1}\right)$ & 245 \\
phosphor $\left(\mathrm{mgkg}^{-1}\right)$ & 3.47 \\
Zinc $\left(\mathrm{mgkg}^{-1}\right)$ & 1.37 \\
Couper $\left(\mathrm{mgkg}^{-1}\right)$ & 1.06 \\
Manganic $\left(\mathrm{mgkg}^{-1}\right)$ & 35 \\
\hline
\end{tabular}

The concentration of $\left(\mathrm{H}^{\mathrm{A}}\right)$ in liquid fertilizer used was $87 \%$ and it is used as a soil additive or as a spray between plants or with irrigation water (in this research we used those four concentrations by springing on the soil within planting lines), while avoiding spray's downfall on the plants, because the spray solution leads to burns the leaves of plants. Where the spray was completely wet to soil and was irrigated after 3 days of each sprayed.

Soil treated with that $\left(\mathrm{H}^{\mathrm{A}}\right)$ different concentration two times during the growing season, first after 3 weeks from complete germination and the second immediately after plant branching, with caution and raking care from the fall of the $\left(\mathrm{H}^{\mathrm{A}}\right)$ spray with any concentration on the leaves because it causes burns in them.

All agricultural services were done (Supplementary irrigation, hoeing or weeding, patching by sowing seeds in the empty holes, sandal by keeping one plant at a distance...) knowing that fertilization was not done, in order to know the effect of hemic acid on vegetative and yield characteristics.

Vegetative growth and yield produced data over cultivation distances and concentrations of $\left(\mathrm{H}^{\mathrm{A}}\right)$ and their interaction of all studied traits (plant height $(\mathrm{cm})$, plant diffusion $(\mathrm{cm})$, number of Brunches / plant, 
number of flowers / plant were recorded after 90 days from sowing the seeds. While the mean number of pods / plant, \% percentage of pods set, total pods yield gm / plant and mean pod weight gm), were recorded at the end of the growing season, and then the statistical variance analysis was performed to determine the significant differences within planting distances, $\left(\mathrm{H}^{\mathrm{A}}\right)$ concentration and their interaction. The mean of these factors was compared with a test of significant difference below the level of L. S. D 0.05. [20].

\section{RESULTS AND DISCUSSIONS}

Plant height (cm): The results indicated in Table 2 showed that, the higher distance between plants, the lower in plant height (inverse relationship). Cultivation of plants on a distance of $20 \mathrm{~cm}$ achieved a significant increase $(81.32 \mathrm{~cm})$ in plant height, followed by a decrease in plant height when cultivating at a distance of $25 \mathrm{~cm}$ (74.98) and this distance achieved a significant decrease from the distance of $30 \mathrm{~cm}(65.91 \mathrm{~cm})$, this is due to decreasing the spaces, plants are more competitive with sunlight and such competition decreases as the increases of distance [4], these results obtained from cultivated broad bean under drip irrigation in that research, also our results were coincide with the findings of [21], but the researcher was conducted his research under rainy conditions . The mean concentration of $3.0 \mathrm{ml}\left(\mathrm{H}^{\mathrm{A}}\right)$ organic fertilizer / liter water, achieved the highest mean length of the plant $(82.07 \mathrm{~cm})$ followed by the concentration of $1.5 \mathrm{ml} /$ liter water $(75.29 \mathrm{~cm})$. It is noteworthy that the concentration of $4.5 \mathrm{ml} /$ liter water $(67.31 \mathrm{~cm})$ had achieved lowest average of plant length, compared with zero concentration $(67.31,71.60 \mathrm{~cm})$. This result corresponds to the finding of [22].

Table 2: Effect of cultivation distances $(\mathrm{cm})$, and $\left(\mathrm{H}^{\mathrm{A}}\right)$ concentration $\mathrm{ml} /$ liter water and their interaction on plant height of Somar broad bean local variety.

\begin{tabular}{|c|c|c|c|c|c|}
\hline \multirow{2}{*}{$\mathbf{A}$} & \multicolumn{4}{|c|}{ B } & \multirow{2}{*}{$\begin{array}{l}\text { Mean } \\
\text { factor } \\
\text { A }\end{array}$} \\
\hline & $\mathbf{b}_{0}$ & $\mathbf{b}_{1}$ & $\mathbf{b}_{2}$ & $\mathbf{b}_{3}$ & \\
\hline $\mathrm{a}_{1}$ & 76.23 & 83.13 & 90.70 & 75.20 & 81.32 \\
\hline $\mathrm{a}_{2}$ & 73.90 & 76.93 & 80.26 & 68.86 & 74.98 \\
\hline $\mathrm{a}_{3}$ & 64.67 & 65.83 & 75.26 & 57.87 & 65.91 \\
\hline $\begin{array}{l}\text { Mean } \\
\text { factor } \\
\text { B }\end{array}$ & 71.60 & 75.29 & 82.07 & 67.31 & \\
\hline \multicolumn{6}{|c|}{$\begin{array}{l}\text { L. S. D } 0.05 \text { Factor A (The distance between plants) }=6.32 \\
\text { L. S. D } 0.05 \text { Factor B (the }\left(\mathrm{H}^{\mathrm{A}}\right) \text { concentrations) }=5.12 \\
\text { L. S. D } 0.05 \text { Interaction A X B }=2.68 \\
\text { a1: } 20 \mathrm{~cm}, \mathrm{a} 2: 25 \mathrm{~cm}, \mathrm{a}: 30 \mathrm{~cm}-\mathrm{b} 0: \text { zero, b1: } 1.5 \mathrm{ml} / \text { liter, b2: } 3.0 \mathrm{ml} \\
\text { / liter, b3: } 4.5 \mathrm{ml} / \text { liter. }\end{array}$} \\
\hline
\end{tabular}

Interaction between mean plant lengths and mean concentrations of the $\left(\mathrm{H}^{\mathrm{A}}\right)$ treatments, showed that the concentration of $3.0 \mathrm{ml} /$ liter water achieved the highest mean length of the remaining plants at a planting distance of $20 \mathrm{~cm}$ followed by the concentration of 1.5 $\mathrm{ml} /$ liter water at a planting distance of $20 \mathrm{~cm}$ and the concentration of $3.0 \mathrm{ml} /$ liter water at a distance of 25 $\mathrm{cm}(90.70,83.13,80.13 \mathrm{~cm}$ respectively).
Plant's diffusion (cm): Result obtained from Table 3 showed that there were no significant differences within the mean of cultivation distances $(\mathrm{cm})$ on plant's diffusion. This result contradicts with the results in research [4] in which the distances of agriculture had a significant effect on the diffusion of plants, because the researchers used agricultural distances greater than the distances we used in our research $(20.30,40 \mathrm{~cm})$. The concentration of $\left(\mathrm{H}^{\mathrm{A}}\right)$ showed that 3 and $1.5 \mathrm{ml} /$ liter water had significant differences together in plant diffusion $(21.05$ and $20.64 \mathrm{~cm})$ compared with zero and $4.5 \mathrm{ml} /$ liter water $(19.55$ and $19.09 \mathrm{~cm})$.

Interaction within plant distances and concentrations of $\left(\mathrm{H}^{\mathrm{A}}\right)$ represented that cultivation on distance 20 and 30 $\mathrm{cm}$ and treated with $3.0 \mathrm{ml} /$ later water $\left(\mathrm{H}^{\mathrm{A}}\right)$ achieved significant differences $(21.33$ and $21.30 \mathrm{~cm})$.

Table 3: Effect of cultivation distances and the $\left(\mathrm{H}^{\mathrm{A}}\right)$ concentrations $\mathrm{ml} /$ liter water and their interaction on plant diffusion of Somar broad bean local variety.

\begin{tabular}{|c|c|c|c|c|c|}
\hline \multirow{2}{*}{$\mathbf{A}$} & \multicolumn{4}{|c|}{ B } & \multirow{2}{*}{$\begin{array}{l}\text { Mean } \\
\text { factor } \\
\text { A }\end{array}$} \\
\hline & $\mathbf{b}_{0}$ & $\mathbf{b}_{1}$ & $\mathbf{b}_{2}$ & $\mathbf{b}_{3}$ & \\
\hline $\mathrm{a}_{1}$ & 19.90 & 20.63 & 21.33 & 19.30 & 20.22 \\
\hline$a_{2}$ & 19.52 & 20.36 & 20.53 & 18.93 & 19.90 \\
\hline$a_{3}$ & 19.23 & 20.93 & 21.30 & 19.03 & 20.12 \\
\hline $\begin{array}{l}\text { Mean } \\
\text { factor } \\
\text { B }\end{array}$ & 19.55 & 20.64 & 21.05 & 19.09 & \\
\hline \multicolumn{6}{|c|}{$\begin{array}{l}\text { L. S. D 0.05 Factor A (The distance between plants) }=1.12 \\
\text { L. S. D } 0.05 \text { Factor B (the }\left(\mathrm{H}^{\mathrm{A}}\right) \text { concentrations) }=0.66 \\
\text { L. S. D } 0.05 \text { Interaction A X B }=0.37 \\
\text { a1: } 20 \mathrm{~cm}, \mathrm{a} 2: 25 \mathrm{~cm}, \mathrm{a}: 30 \mathrm{~cm}-\mathrm{b} 0: \text { zero, b1: } 1.5 \mathrm{ml} / \text { liter, b2: } 3.0 \mathrm{ml} \\
\text { / liter, b3: } 4.5 \mathrm{ml} / \text { liter. }\end{array}$} \\
\hline
\end{tabular}

Number of branches / plant: The results obtained in Table 4 indicated that the plant distance of 30 and $25 \mathrm{~cm}$ between plants had indicated significant differences together (5.58 and 5.13 branches / plant) comparing with $20 \mathrm{~cm}$ (4.10 branches / plant), those results contrary to what they got by [23] where it was found that the distance $40 \mathrm{~cm}$ between the plants made a significant difference from $30 \mathrm{~cm}$. Concentrations of 3 and $1.5 \mathrm{ml} /$ liter water of $\left(\mathrm{H}^{\mathrm{A}}\right)$ achieved significant differences together comparing with zero and $4.5 \mathrm{ml} /$ liter water, knowing that the concentration of zero was significantly higher than the $4.5 \mathrm{ml} /$ liter water, those results coincide with the finding of [22], whereas the researchers finding that the concentration of $3 \mathrm{ml} /$ liter water was significantly than $1.5 \mathrm{ml} /$ liter water in that research, this is due to the addition of $\left(\mathrm{H}^{\mathrm{A}}\right)$ to the tank of the drip irrigation system and adding it in the drip irrigation method .

Interaction within plant distances and different concentrations of $\left(\mathrm{H}^{\mathrm{A}}\right)$ showed that cultivation faba bean at the distance of $30 \mathrm{~cm}$ and treating the soil with $3.0 \mathrm{ml}$ / liter water $\left(\mathrm{H}^{\mathrm{A}}\right)$ achieved higher significant differences (6.8 branches / plant). Followed significantly by cultivation with the same distance and treated the soil with $1.5 \mathrm{ml} /$ liter water ( 6.3 branches / plant), then comes after this, cultivation at a distance of $25 \mathrm{~cm}$ and treated soil with $3.0 \mathrm{ml} /$ liter water (5.9 branches/ plant), these results were relatively consistent with what reached by [3], but the researcher used plant distances 
(20, 30, $40 \mathrm{~cm}$ within plant and $50 \mathrm{~cm}$ between rows) and soil treated with zero, 2, 4, $6 \mathrm{ml} /$ liter water concentrations of $\left(\mathrm{H}^{\mathrm{A}}\right)$ in his work.

Table 4: Effect of cultivation distances $(\mathrm{cm})$, and $\left(\mathrm{H}^{\mathrm{A}}\right)$ concentrations $\mathrm{ml} /$ liter water and their interaction on number of branches / plant of Somar broad bean local variety.

\begin{tabular}{|c|c|c|c|c|c|}
\hline \multirow{2}{*}{$\mathbf{A}$} & \multicolumn{4}{|c|}{ B } & \multirow{2}{*}{$\begin{array}{c}\text { Mean } \\
\text { factor } \\
\text { A } \\
\end{array}$} \\
\hline & $b_{0}$ & $\mathbf{b}_{1}$ & $\mathbf{b}_{2}$ & $\mathbf{b}_{3}$ & \\
\hline$a_{1}$ & 4.1 & 4.8 & 4.3 & 3.2 & 4.10 \\
\hline$a_{2}$ & 5.3 & 5.6 & 5.9 & 3.7 & 5.13 \\
\hline $\mathrm{a}_{3}$ & 5.2 & 6.3 & 6.8 & 4.0 & 5.58 \\
\hline $\begin{array}{c}\text { Mean } \\
\text { factor } \\
\text { B }\end{array}$ & 4.89 & 5.57 & 5.67 & 3.63 & \\
\hline
\end{tabular}

L. S. D 0.05 Factor A (The distance between plants) $=1.11$

L. S. $\mathrm{D}_{0.05}$ Factor $\mathrm{B}$ (the $\left(\mathrm{H}^{\mathrm{A}}\right)$ concentrations) $=0.68$

L. S. D 0.05 Interaction A X B $=0.39$

a1: $20 \mathrm{~cm}, \mathrm{a} 2: 25 \mathrm{~cm}, \mathrm{a} 3: 30 \mathrm{~cm}$ - b0: zero, b1: $1.5 \mathrm{ml} /$ liter, b2: $3.0 \mathrm{ml}$ / liter, b3: $4.5 \mathrm{ml} /$ liter.

Number of flowers / plant: Results from Table 5 indicated that there were not significant differences within plant distances. For $\left(\mathrm{H}^{\mathrm{A}}\right)$ different concentrations, those results were explained that 3.0 and $1.5 \mathrm{ml} /$ liter water together achieved significantly (5.67 and 5.57 flowers / plant) comparing with zero and $4.5 \mathrm{ml} /$ liter water $\left(\mathrm{H}^{\mathrm{A}}\right)$ concentrations (4.89 and 4.63 flowers / plant), knowing that zero achieved a relative superiority than $4.5 \mathrm{ml} /$ liter water concentration $\left(\mathrm{H}^{\mathrm{A}}\right)(33.67,30.56$ flowers / plant respectively), but this superiority was not significant, those results did not corresponded with the findings of [9] because the researchers treated the soil 3 times during the season in that research and not twice as in our research.

Table 5: Effect of cultivation distances $(\mathrm{cm})$, and $\left(\mathrm{H}^{\mathrm{A}}\right)$ concentrations $\mathrm{ml} /$ liter water and their interaction on number of flowers / plant of the broad bean local variety (Somar).

\begin{tabular}{|c|c|c|c|c|c|}
\hline \multirow{2}{*}{ A } & \multicolumn{4}{|c|}{ B } & \multirow{2}{*}{$\begin{array}{l}\text { Mean } \\
\text { factor } \\
\text { A }\end{array}$} \\
\hline & $\mathbf{b}_{0}$ & $\mathbf{b}_{1}$ & $\mathbf{b}_{2}$ & $\mathbf{b}_{3}$ & \\
\hline $\mathrm{a}_{1}$ & 36.67 & 46.33 & 51.00 & 31.67 & 41.42 \\
\hline$a_{2}$ & 34.67 & 40.00 & 43.67 & 31.00 & 37.34 \\
\hline$a_{3}$ & 29.67 & 41.33 & 44.67 & 29.00 & 36.17 \\
\hline $\begin{array}{l}\text { Mean } \\
\text { factor } \\
\text { B }\end{array}$ & 33.67 & 45.55 & 46.45 & 30.56 & \\
\hline \multicolumn{6}{|c|}{$\begin{array}{l}\text { L. S. D } 0.05 \text { Factor A (The distance between plants) }=9.44 \\
\text { L. S. D } 0.05 \text { Factor B (the }\left(\mathrm{H}^{\mathrm{A}}\right) \text { concentrations) }=6.13 \\
\text { L. S. D } 0.05 \text { Interaction A X B }=3.18 \\
\text { a1: } 20 \mathrm{~cm}, \mathrm{a} 2: 25 \mathrm{~cm}, \mathrm{a3}: 30 \mathrm{~cm}-\mathrm{b} 0: \text { zero, b1: } 1.5 \mathrm{ml} / \text { liter, b2: } 3.0 \mathrm{ml} \\
\text { / liter, b3: } 4.5 \mathrm{ml} / \text { liter. }\end{array}$} \\
\hline
\end{tabular}

Interaction within plant distances and $\left(\mathrm{H}^{\mathrm{A}}\right)$ concentrations achieved significantly when cultivated plants on $20 \mathrm{~cm}$ within plants and spread the soil with concentration of $3.0 \mathrm{ml} /$ liter water $\left(\mathrm{H}^{\mathrm{A}}\right)$ (51.0 flowers / plant), these results contradict what they had reached by [3], where they obtained significantly on a distance of 30 $\mathrm{cm}$ and treatment of soil at a concentration of $4.5 \mathrm{ml} /$ liter water $\left(\mathrm{H}^{\mathrm{A}}\right)$.
Number of pods / plant: Results from Table 6 indicated that there were no significant differences among plant distances. The concentration of 3 and 1.5 $\mathrm{ml} /$ liter water $\left(\mathrm{H}^{\mathrm{A}}\right)$ were obtained together a significant effect comparing with zero and $4.5 \mathrm{ml} /$ liter water, these results coincide with the findings of [9].

Interactions between plant distances and the $\left(\mathrm{H}^{\mathrm{A}}\right)$ concentrations showed that there were significant effects when the cultivation distance of $30 \mathrm{~cm}$ between a plant and another and the soil treated with concentration of $3.0 \mathrm{ml} /$ liter water $\left(\mathrm{H}^{\mathrm{A}}\right)$, followed by cultivation with the same distances and the soil treated with concentration of $1.5 \mathrm{ml} /$ liter water .

Table 6: Effect of cultivation distances $(\mathrm{cm})$, and $\left(\mathrm{H}^{\mathrm{A}}\right)$ concentrations $\mathrm{ml} /$ liter water and their interaction on number of pods / plant of the broad bean local variety (Somar).

\begin{tabular}{|c|c|c|c|c|c|}
\hline \multirow{2}{*}{$\mathbf{A}$} & \multicolumn{4}{|c|}{ B } & \multirow{2}{*}{$\begin{array}{c}\text { Mean } \\
\text { factor } \\
\text { A }\end{array}$} \\
\hline & $\mathbf{b}_{0}$ & $\mathbf{b}_{1}$ & $\mathbf{b}_{2}$ & $\mathbf{b}_{3}$ & \\
\hline$a_{1}$ & 11.67 & 14.00 & 17.67 & 11.67 & 13.75 \\
\hline$a_{2}$ & 13.00 & 17.33 & 20.00 & 13.00 & 15.83 \\
\hline $\mathrm{a}_{3}$ & 13.67 & 21.67 & 23.67 & 14.33 & 18.34 \\
\hline $\begin{array}{c}\text { Mean } \\
\text { factor } \\
\text { B } \\
\end{array}$ & 12.78 & 17.67 & 20.45 & 13.00 & \\
\hline $\begin{array}{l}\text { L. S. D } 0.05 \\
\text { L. S. D } 0.05 \\
\text { L. S. D } 0.05 \\
\text { a1: } 20 \mathrm{~cm}, \\
/ \text { liter, b3: }\end{array}$ & $\begin{array}{l}\text { actor A (T } \\
\text { factor B (t } \\
\text { nteraction } \\
25 \mathrm{~cm}, \mathrm{a} 3 \\
\mathrm{ml} / \text { liter. }\end{array}$ & $\begin{array}{l}\text { distanc } \\
\left(\mathrm{H}^{\mathrm{A}}\right) \mathrm{co} \\
\mathrm{X} \mathrm{B} \mathrm{=} \\
30 \mathrm{~cm}-\mathrm{b}\end{array}$ & $\begin{array}{l}\text { between } \\
\text { centratic } \\
.93 \\
: \text { zero, b }\end{array}$ & $\begin{array}{l}\text { ants) }=6 \\
=4.18 \\
1.5 \mathrm{ml} / 1\end{array}$ & $\mathrm{~b} 2: 3.0 \mathrm{~m}$ \\
\hline
\end{tabular}

\% Percentage of pods set: Table 7 illustrated that increasing the agricultural distances between plants led to increasing in hundred percentages of pods set, since the cultivation of plants at $30 \mathrm{~cm}$ distance within plants achieved significantly (50.96\% percentage pods set) than cultivation on $25 \mathrm{~cm}$ (42.69\% percentage pods set) and this distance achieved significant effect than $20 \mathrm{~cm}$ (34.14\% percentage pods set).

Table 7: Effect of cultivation distances $(\mathrm{cm})$, and $\left(\mathrm{H}^{\mathrm{A}}\right)$ concentrations $\mathrm{ml} /$ liter water and their interaction on the \% percentages of pods set of the broad bean local variety (Somar).

\begin{tabular}{|c|c|c|c|c|c|}
\hline \multirow{2}{*}{$\mathbf{A}$} & \multicolumn{4}{|c|}{ B } & \multirow{2}{*}{$\begin{array}{c}\text { Mean } \\
\text { factor } \\
\text { A }\end{array}$} \\
\hline & $b_{0}$ & $\mathbf{b}_{1}$ & $\mathbf{b}_{2}$ & $\mathbf{b}_{3}$ & \\
\hline $\mathrm{a}_{1}$ & 31.82 & 33.22 & 34.65 & 36.85 & 34.14 \\
\hline$a_{2}$ & 37.50 & 43.33 & 48.00 & 41.94 & 42.69 \\
\hline$a_{3}$ & 46.07 & 52.43 & 55.91 & 49.41 & 50.96 \\
\hline $\begin{array}{c}\text { Mean } \\
\text { factor } \\
\text { B }\end{array}$ & 38.46 & 42.99 & 46.18 & 42.73 & \\
\hline $\begin{array}{l}\text { L. S. D } 0 .( \\
\text { L. S. D } 0 .( \\
\text { L. S. D } 0 .( \\
\text { a1: } 20 \mathrm{~cm} \text {, } \\
\mathrm{ml} / \text { liter, }\end{array}$ & $\begin{array}{l}\text { Factor A } \\
\text { Factor B } \\
\text { Interactic } \\
2: 25 \mathrm{~cm} \text {, } \\
: 4.5 \mathrm{ml} / \\
\end{array}$ & $\begin{array}{l}\text { The distal } \\
\text { the }\left(\mathrm{H}^{\mathrm{A}}\right) \\
\text { A X B } \\
3: 30 \mathrm{~cm} \\
\text { ter. }\end{array}$ & $\begin{array}{l}\text { e betwee } \\
\text { ncentrat } \\
3.09 \\
0 \text { : zero, }\end{array}$ & $\begin{array}{l}\text { plants) }= \\
\text { s) }=5.1 \\
: 1.5 \mathrm{ml}\end{array}$ & b2: 3.0 \\
\hline
\end{tabular}

This is due to the increased distance within plants leads to increases the dynamic range of root growth and its branching, which provides more water and food to the plant in order to form more flowers and hence the formation of pods [3]. For the $\left(\mathrm{H}^{\mathrm{A}}\right)$ concentration, the 
treatment of $3.0 \mathrm{ml} /$ liter water achieved significant effect ( $46.18 \%$ percentage pods set) comparing with zero concentration (38.46\% percentage pods set), this result did not match what had reached [24], because the researchers conducted their research under rainy conditions.

Interaction within cultivation distances and $\left(\mathrm{H}^{\mathrm{A}}\right)$ differences concentrations showed that cultivation plants at distance of $30 \mathrm{~cm}$ and soil treated with $3.0 \mathrm{ml} /$ liter $\left(\mathrm{H}^{\mathrm{A}}\right)$ achieved significant effect $(55.91 \%$ percentage pods set), followed significantly by the same distance and soil treated with $1.5 \mathrm{ml} /$ liter water $\left(\mathrm{H}^{\mathrm{A}}\right)(52.43 \%$ percentage pods set), then come after this treatment, the plants cultivation at $25 \mathrm{~cm}$ and treating the soil with 3.0 $\mathrm{ml} /$ liter water $\left(\mathrm{H}^{\mathrm{A}}\right)$ (48.00\% percentage pods set), this results corresponding with the findings of [3].

Total pods yield /plant(gm): Results in Table 8 illustrated that the greater distance within plants, the greater total yield gm / plant, so the cultivation of plants with distance $30 \mathrm{~cm}$ had got significant effect $(356.75$ gm / plant) of cultivation on the distance $25 \mathrm{~cm}(292.08$ gm /plant), and this treatment was significant compared to the distance $20 \mathrm{~cm}(234.20 \mathrm{gm} /$ plant $)$, Those results were relatively consistent with the findings of [25], but the researchers used six plant densities $(13,25,38,50,63$ and 75 plants. $\mathrm{m}^{-2}$ ) in there research.

For the $\left(\mathrm{H}^{\mathrm{A}}\right)$ concentrations, those results showed that $3.0 \mathrm{ml} /$ liter water had achieved significant effect (378.45 gm / plant) followed significantly by concentration of $1.5 \mathrm{ml} /$ liter water (322.11 gm / plant) comparing with $4.5 \mathrm{ml} /$ liter. and zero concentrations (242.11 and $234.78 \mathrm{gm} \mathrm{/} \mathrm{plant),} \mathrm{those} \mathrm{results} \mathrm{were}$ relatively consistent with the findings of [22], but the research was done under aluminum toxicity in growth room.

Table 8: Effect of cultivation distances $(\mathrm{cm})$, and $\left(\mathrm{H}^{\mathrm{A}}\right)$ concentrations $\mathrm{ml} /$ liter water and their interaction on total yield ( $\mathrm{gm} / \mathrm{plant}$ ) of the broad bean local variety (Somar).

\begin{tabular}{|c|c|c|c|c|c|}
\hline \multirow{2}{*}{$\mathbf{A}$} & \multicolumn{4}{|c|}{ B } & \multirow{2}{*}{$\begin{array}{l}\text { Mean } \\
\text { factor } \\
\text { A }\end{array}$} \\
\hline & $\mathbf{b}_{0}$ & $\mathbf{b}_{1}$ & $\mathbf{b}_{2}$ & $\mathbf{b}_{3}$ & \\
\hline$a_{1}$ & 204.00 & 248.33 & 273.67 & 211.00 & 234.20 \\
\hline$a_{2}$ & 243.33 & 310.33 & 391.00 & 223.67 & 292.08 \\
\hline$a_{3}$ & 257.00 & 407.67 & 470.67 & 291.67 & 356.75 \\
\hline $\begin{array}{l}\text { Mean } \\
\text { factor } \\
\text { B }\end{array}$ & 234.78 & 322.11 & 378.45 & 242.11 & \\
\hline \multicolumn{6}{|c|}{$\begin{array}{l}\text { L. S. D } 0.05 \text { Factor A (The distance between plants) }=47.11 \\
\text { L. S. D } 0.05 \text { Factor B (the }\left(\mathrm{H}^{\mathrm{A}}\right) \text { concentrations) }=30.29 \\
\text { L. S. D } 0.05 \text { Interaction A X B }=15.88 \\
\text { a1: } 20 \mathrm{~cm}, \mathrm{a} 2: 25 \mathrm{~cm}, \mathrm{a}: 30 \mathrm{~cm}-\mathrm{b} \text { : zero, b1: } 1.5 \mathrm{ml} / \text { liter, b2: } 3.0 \mathrm{ml} \\
\text { / liter, b3: } 4.5 \mathrm{ml} / \text { liter. }\end{array}$} \\
\hline
\end{tabular}

Interaction within plant distances and different concentrations of $\left(\mathrm{H}^{\mathrm{A}}\right)$ showed that cultivation broad bean at a distance of $30 \mathrm{~cm}$ and treated the soil with 3.0 $\mathrm{ml} /$ liter had got significant effect (470.67 gm / plant) followed significantly by cultivation with the same distance and treating the soil with $1.5 \mathrm{ml} / \operatorname{liter}\left(\mathrm{H}^{\mathrm{A}}\right)$ concentration (407.67 gm / plant), and then this was follows significantly by cultivation the plants at $25 \mathrm{~cm}$ distance and soil's treated with $3.0 \mathrm{ml} /$ liter $\left(\mathrm{H}^{\mathrm{A}}\right)$ concentration (391.00 gm / plant).

Mean pods weight $(\mathbf{g m})$ : From Table 9 indicated that cultivation broad bean at the distance of $30 \mathrm{~cm}$ had got significant effect (7.25 gm / pod) comparing with the distance of $20 \mathrm{~cm}(5.15 \mathrm{gm} / \mathrm{pod})$. For the different concentrations of Humic acid, the treatment of $3 \mathrm{ml} /$ liter had achieved significantly (7.33 gm / pod) followed significantly by the treatment of $1.5 \mathrm{ml} /$ liter $(6.43 \mathrm{gm} /$ pod) comparing with zero and $4.5 \mathrm{ml} /$ liter (5.67 and $5.26 \mathrm{gm} /$ pod).

Interaction within plant distances and different concentrations of $\left(\mathrm{H}^{\mathrm{A}}\right)$ showed that, cultivation broad bean plant at the distance $30 \mathrm{~cm}$ and soil treated with 3.0 $\mathrm{ml} /$ liter water had achieved significant effect (8.7 gm / pod) followed significantly by cultivation with the same distance and treating the soil $1.5 \mathrm{ml} /$ liter water, then follows significantly by cultivation plants at the distance $25 \mathrm{~cm}$ and treating the soil with $3 \mathrm{ml} /$ liter water $(7.3$ $\mathrm{gm} / \mathrm{pod})$.

Table 9: Effect of cultivation distances $(\mathrm{cm})$, and $\left(\mathrm{H}^{\mathrm{A}}\right)$ concentrations $\mathrm{ml} /$ liter and their interaction on total yield ( $\mathrm{gm}$ / pod) of the Somar broad bean local variety.

\begin{tabular}{|c|c|c|c|c|c|}
\hline \multirow{2}{*}{$\mathbf{A}$} & \multicolumn{4}{|c|}{ B } & \multirow{2}{*}{$\begin{array}{l}\text { Mean } \\
\text { factor } \\
\quad \text { A }\end{array}$} \\
\hline & $\mathbf{b}_{0}$ & $\mathbf{b}_{1}$ & $\mathbf{b}_{2}$ & $\mathbf{b}_{3}$ & \\
\hline $\mathrm{a}_{1}$ & 5.0 & 5.3 & 6.0 & 4.3 & 5.15 \\
\hline $\mathrm{a}_{2}$ & 5.7 & 6.3 & 7.3 & 5.2 & 6.13 \\
\hline $\mathrm{a}_{3}$ & 6.3 & 7.7 & 8.7 & 6.3 & 7.25 \\
\hline $\begin{array}{l}\text { Mean } \\
\text { factor } \\
\text { B }\end{array}$ & 5.67 & 6.43 & 7.33 & 5.26 & \\
\hline \multicolumn{6}{|c|}{$\begin{array}{l}\text { L. S. D } 0.05 \text { Factor A (The distance between plants) }=1.55 \\
\text { L. S. D } 0.05 \text { Factor B (the }\left(\mathrm{H}^{\mathrm{A}}\right) \text { concentrations) }=0.83 \\
\text { L. S. D } 0.05 \text { Interaction A X B = } 0.39 \\
\text { a1: } 20 \mathrm{~cm}, \mathrm{a} 2: 25 \mathrm{~cm}, \mathrm{a3}: 30 \mathrm{~cm}-\mathrm{b} 0: \text { zero, b1: } 1.5 \mathrm{ml} / \text { liter, b2: } 3.0 \mathrm{ml} \\
/ \text { liter, b3: } 4.5 \mathrm{ml} / \text { liter. }\end{array}$} \\
\hline
\end{tabular}

\section{CONCLUSION}

Through the results obtained in our research, we can conclude the following: For the cultivated distances: The higher distance between plants significantly (inverse relationship) with plant height. The 30 and $25 \mathrm{~cm}$ distances significantly increase number of branches comparing with $20 \mathrm{~cm}$. The $30 \mathrm{~cm}$ distances increases percentage of pods set, and yield (gm /plant). For the different concentrations of $\left(\mathrm{H}^{\mathrm{A}}\right)$ : The concentration of $3.0 \mathrm{ml} /$ liter water was affected significantly to increase plant height $(\mathrm{cm})$, yield (gm / plant) and mean pod weight. While the concentration of 3.0 and $1.5 \mathrm{ml} /$ liter water were affected significantly to increase plants diffusion $(\mathrm{cm})$, number of branches / plant, number of flower / plant, number of pods / plant and \% percentage of pods set. For the interaction: The cultivation plants with distance $20 \mathrm{~cm}$ and soil treated with $3.0 \mathrm{ml} /$ liter water had achieved significant in plant height $(\mathrm{cm})$ and number of flowers / plant. While in the rest characters, the cultivated plants as a distance of $30 \mathrm{~cm}$ and treated the soil with $3.0 \mathrm{ml} /$ liter water such as number of brings / plant, total yield (gm / plant) and mean pod weight or cultivation with the same distance and treated with 3.0 or $1.5 \mathrm{ml} /$ liter water such as number of pods / plant and \% 
percentage of pods set. These results indicated that cultivated faba bean plants at a distance of $30 \mathrm{~cm}$ between plants and treating the soil with $3.0 \mathrm{ml} /$ liter water obtained on better characteristics in most studied traits

\section{REFERENCES}

[1] H. Allayer, T. Brady, "Classification and Botanical Description of Legumes",University of Cambridge - Annual Report (England), 2010

[2] F. Etemadi, Dr.M. Hashemi, Dr.F. Mangan, Dr.S. Weis, FAVA BEANS: Growers Guide in New England, Massachusetts Amherst University (New England), 2015.

[3] K. L. Peterson," Effect of Humic Acids and Plants Densities on Growth, and Productivity of Two Broad Bean Varieties",A Thesis Submitted to the Faculty of Miami University in partial fulfillment of the requirements for the Master degree of Science. Miami University. Ohio, 2017.

[4] N. N. Ameer, D. Ahmad, A. S. Abdullahi, "The effect of planting distance on the growth and yield of beans (Vicia faba L.) under drip irrigation system", African Journal of Agricultural Research Vol. 7(46), pp. 6110-6114, 2012.

[5] N.Al-Suhaibani, S. El-Hendawy1, U. Schmidhalter, "Influence of Varied Plant Density on Growth, Yield of Faba bean Vicia faba, L", Turkish Journal of Field Crops 18(2), and 185-197, 2013.

[6] B.A. Bakry; T.A. Elewa; M.F. El karamany; M.S. Zeidan , M.M. Tawfik, "Effect of Row Spacing on Yield and its Components of Some Faba Bean Varieties under Newly Reclaimed Sandy Soil Condition", Department of Field Crops Research, National Research Centre, Giza, Egypt. World Journal of Agricultural Sciences 7 (1): 68-72, 2011.

[7] Grower Note, Faba bean. "Research on Unregistered Agricultural Chemical Use," Grower Research and Development Cooperation GRDC ISBN: 978-1-921779-09-1, 2017.

[8] A.N. Matlowb, A.d. S. Mohamad, K.S. Abdul, "Vegetable Production - Part one", University of Mosul Press Ministry of Higher Education and Scientific Research. Iraq, 1980.

[9] J. W. Patri, F. L. Stoddard, "Physiology of flowering and grain filling in faba bean", Field Crops Research 115 (3):234-242 University of Helsinki. Finland, 2010.

[10] I. G. Ayu, M. S. Agung, "Studies on pod and seeds growth of faba bean Vicia faba, L. under rain fed of water stress and high temperature", Thesis submitted for the degree of doctor of philosophy. University of Adelaide - Faculty of Agricultural and Natural Resource Science - Department of Plant Science, 1995.

[11] "Broad bean cultivation", Agricultural Bulletin. Directorate of General Agricultural Archives. Ministry of Agriculture Baghdad - Iraq, 2015.

[12] Y. Genk, G,Lyons, "Replenishing Humic Acids in Agricultural Soils", Agronomy Communication. Australia; michael@biogon.com.au, 2016.

[13] Anonyms, "Soil Biotics, What Is Humic Acid? and Where Does It Come from?", Research for results, www.soilbiotics.com, 2010.

[14] S.. Akinch, T. Buyukkeskin, A. Eroglu, B. Eygi, "The Effect of (H.A) on Nutrient Composition in Broad Bean (Vicia faba L.) Roots", ISSN 2067-3205; Electronic 2067-3264. Note Science Biology 1 (1) pp: 81-87,2009.

[15] V. Mora, J. M.Garcia-Mina, M. Olaetxea, Jean-c. Yvin, "Main mechanisms involved in the effects of Humic substances on soilplant systems". Agrociencia 16:188-190. Universidad de Navarra, 2012.

[16] A. A. Hassan, A. M. Salim, "Effect of spraying of (H.A) on the growth and yield of two varieties of potatoes",Diyala Journal of Agricultural Research. Volume 3 (2): 712 - 721. Diyala - Iraq, 2011.

[17] M. A. Ali and A. J. Mjeed, "Biochar and Nitrogen Fertilizers Effects on Growth and Flowering of Garland Chrysanthemum (Chrysanthemum Coronarium L.) Plant," KJAR, 2(1), pp. 8-14, 2017.

[18] A. J. Mjeed, M. A. Ali, "Effect of Gyttja and Nitrogen Applications on Growth and Flowering of Snapdragons (Antirrhinum majus L.) Plant in the Two Soils Depth," KJAR, 2(1), pp. 1-7, 2017.
[19] R. A. Qadir, H. M. Amin,A. J. Mjeed, "Effect of growing seasons, plant extracts with various rates on Black Bean Aphid, Aphis Fabae (Aphididae: Homoptera)," KJAR, 3(1), pp. 22-26, 2018.

[20] H. J. Seltman,'Experimental Design and Analysis", Book is on the World Wide Web, 2018.

[21] A. N. N. Kakahy, D. Ahmad1, A. S. Abdullahi, "The effect of planting distance on yield of beans (Vicia faba L.) Under drip irrigation system". African Journal of Agricultural Research Vol. 7(46), 110-114. Academic Journals, 2012.

[22] T. B., S. Akinci, A. E. Eroğlu, "Effects of $\left(\mathrm{H}^{\mathrm{A}}\right)$ on Root Development and Nutrient Uptake of Vicia faba L. (Broad Bean) Seedlings Grown under Aluminum Toxicity". Communications in Soil Science and Plant Analysis, 46:277292,2015

[23] A.M. Gezahegn; K. Tesfaye, J.J. Sharma, M.D. Belel,' Determination of optimum plant density for faba bean (Vicia faba L.)", on verticals at Haramaya, Eastern Ethiopia. Soil \& Crop Science Research, 2016.

[24] A.Kholdi, S. Sedaghathoor, E.Poursafarali, "Effect of nitroxin and (h.a) on yield andyield components of faba bean under rainy condition", Journal of Agricultural Sciences Vol. 60, No. 3, Pages 361-367. Islamic Azad University, Rasht, Iran, 2015.

[25] R. J. Grav, G. G. Rowi, "Effect of plant density on yield and components of yield of faba bean", Canadian journal of plant science. Vol. 67 (1); 1 - 10 Agronomy section, 1987. 